\title{
A NO'TE ON SOURCES
}

I

n preparing this study, I have drawn most heavily on the papers of Judge Patterson in the Manuscript Division of the Library of Congress. Fortunately for the researcher, this collection (which originally was assembled and organized by Lucille Mundy, Patterson's conscientious assistant of many years) includes copies of most of the important papers that crossed his desk throughout the period of his service in the War Department. Copies of many of these documents can also be found in official War Department records-especially Record Group 107-of the National Archives.

I have also consulted relevant materials in many other public and private archives, including the Franklin D. Roosevelt Presidential Library at Hyde Park, New York; the Harry Truman Presidential Library in Independence, Missouri; the Herbert Hoover Presidential Library in West Branch, Iowa; the Center of Military History, Department of the Army, in Washington, D.G.; the U.S. Army's Military History Institute at Carlisle Barracks, Pennsylvania; the United States Military Academy Library at West Point, New York; the George C. Marshall Library in Lexington, Virginia; the Douglas MacArthur Memorial Library in Norfolk, Virginia; the Libraries of Columbia, Princeton, and Yale Universities; private papers in the possession of the Patterson family; and the Library of the Association of the Bar of the City of New York.

Interviews with many of the individuals who knew and worked with 


\section{XVI}

\section{A NOTE ON SOURCES}

Judge Patterson have been especially useful. A list of these people is provided in Appendix A.

A more detailed and fully annotated account of Patterson's life before he went to Washington can be found in my unpublished doctoral dissertation, "The Constant Service: A Biography of Robert P. Patterson," Harvard University, 1974.

Except as otherwise indicated, all citations in footnotes and endnotes refer to documents (letters; memoranda; copies of speeches and Congressional testimony; press releases and newspaper clippings; reports, circulars, and other official documents; and so forth) contained in the Robert P. Patterson papers, Manuscript Division, Library of Congress. 


\section{MOBILIZING AMERICA}


